\title{
Orange wheat blossom midge, Sitodiplosis mosellana (Géhin) (Dipt., Cecidomyidae), on wheat in Finland
}

\author{
JUHA HELENIUS ${ }^{1}$, JYRKI TOMMINEN ${ }^{1}$ and REIJO BJÖRKBACKA ${ }^{2}$ \\ ${ }^{\prime}$ Department of Agricultural and Forest Zoology, University of Helsinki, \\ SF-00710 HELSINKI, Finland \\ ${ }^{2}$ Kymenlaakso Research Station, Agricultural Research Centre, \\ $S F-46910$ ANJALA, Finland
}

\begin{abstract}
Sitodiplosis mosellana has been found for the first time infesting wheat in Finland. In the wheat field studied, the egg laying period was in mid July, and the larvae left the ears in mid August. On an average ca. $20 \%$ of the ears were infested. It was estimated, that $1.7 \%$ of the grains were sucked by the larvae. The level of infestation was found to differ between wheat varieties.
\end{abstract}

\section{Introduction}

The orange wheat blossom midge, Sitodiplosis mosellana (Géhin) (Diptera, Cecidomyidae), occurs as an occasional pest of wheat throughout the wheat-producing countries in the Northern Hemisphere (e.g. BARNES 1956), including the northernmost wheat area in Scandinavia.

Recently, S. mosellana was reported to be a more serious pest than the related species Contarinia tritici Kirby in the Netherlands and Poland (NiJveld \& BoKhorst 1973, GotęBIOWSKA 1980). It was estimated, that 3 or more larvae per grain makes the crop unacceptable for human consumption (NIJVELDT \& BOKHORST 1973).

In Sweden, the life history, economic importance and methods of control of S. mo- sellana, together with those of $C$. tritici, were studied in the 1930s. S. mosellana was found in smaller numbers and was considered to be less important than C. tritici (LindBLom \& Múnlow 1932, MüHLow 1935, 1936, МüHLOW \& SJöberg 1937, SWÄrdSON 1940). Until recently, the damage to wheat in that country was caused by the latter species. In 1979, however, sudden, severe damage was caused by $S$. mosellana in Skåne county, the losses averaging $500 \mathrm{~kg}$ per ha (ANDERSSON \& NiLSSON 1980). In 1981 also there was heavier infestation by $S$. mosellana than by $C$. tritici in Sweden (AHRÉn 1982).

In Finland, only the lemon wheat blossom midge, $C$. tritici was found earlier in wheat (see VAPpUla 1962), S. mosellana being reported from rye (e.g. HuKKINEN \& VAPPULA 
1936). Neither of the midges was considered a serious pest.

In 1983, marked damage to spring wheat was noted in some localities in Southeastern Finland and was suspected to be caused by the wheat midge. The purpose of the present study was to find out whether wheat midges were in fact responsible for the damage.

\section{Material and methods}

In summer 1984 the infestation of spring wheat var. Hankkija's Taava by midges was estimated in a 1.6 ha farm field in Anjalankoski, Southeastern Finland. The study field was situated $10 \mathrm{~km} \mathrm{SW}$ of Kymenlaakso Research Station. The soil type was silty clay (humous), $\mathrm{pH}$ 6.3. The wheat was sown on 17 May.

This field was chosen because it was one of the most seriously damaged in 1983 . The wheat yield in that year was only $1500 \mathrm{~kg}$ per ha, and of poor quality.

From 29 June to 31 Aug. 60 wheat ears were sampled at random every 3 rd or 4 th day along a south-east transect. The ears were inspected for midge eggs or larvae, and the level of infestation was examined on 135 ears collected in the later part of larval development, but before the larvae started to leave the ears (31 July to 7 August).

Falling traps were used in the period when the larvae were leaving the ears and falling to the ground. Three pairs of traps were placed at equal intervals along the transect: Ten wheat ears were bent over a 12-cm-diameter funnel and covered with clear plastic so, that every larva leaving an ear was forced into the funnel. The larvae were collected in a changeable tube at the end of the funnel. The frame holding the funnel allowed vertical adjustment to the growth of the wheat. The trapping period lasted from 20 July to 31 Aug. The tubes were emptied on the same occasions when the ears were sampled.

At Kymenlaakso Research Station, samples were taken from 25 spring wheat varieties. On 16 and 17 Aug., 30 ears were taken per variety and replicate. There were two replicates. The ears were inspected for midge larvae.

According to measurements at Utti weather station $18 \mathrm{~km} \mathrm{NE}$ of Kymenlaakso Research Station, the weather during the study period in 1984 was fairly near to normal. The spring was warmer and drier, and the rainfall in June and July was heavier than usual. The weather in the study year was similar to that in 1983 (Table 1).

Adult midges were collected from wheat stands on 22 July at Hankkija Plant Breeding Station, Anttila, $35 \mathrm{~km} \mathrm{~N}$ of Helsinki, and on 28 July at Helsinki University Experiment Farm, Helsinki.

\section{Results}

Only $S$. mosellana was found. There was no evidence of $C$. tritici.

The first $S$. mosellana eggs were found in

Table 1. Deviations of temperature $\left({ }^{\circ} \mathrm{C}\right)$ and rainfall $(\mathrm{mm})$ in April-August 1983 and 1984 from the means of the period 1931-1960 (normal) at Utti Weather Station.

\begin{tabular}{|c|c|c|c|c|c|c|c|}
\hline & \multirow[b]{3}{*}{$\cdot$} & \multicolumn{3}{|c|}{ Daily mean temperature } & \multicolumn{3}{|c|}{ Rainfall } \\
\hline & & \multicolumn{2}{|c|}{ Deviation } & \multirow[t]{2}{*}{ Normal } & \multicolumn{2}{|c|}{ Deviation } & \multirow[t]{2}{*}{ Normal } \\
\hline & & 1983 & 1984 & & & 1984 & \\
\hline April & & +3.0 & +2.1 & 2.2 & -12.0 & -24.4 & 36 \\
\hline May & & +2.8 & +4.3 & 9.2 & -11.3 & -11.6 & 42 \\
\hline June & & -1.0 & -0.8 & 14.7 & +37.6 & +17.1 & 53 \\
\hline July & & +0.4 & -2.2 & 17.6 & -52.0 & +38.3 & 80 \\
\hline August & & -0.6 & -1.3 & 15.7 & -19.0 & -28.1 & 74 \\
\hline
\end{tabular}


the florets on 3 July, at the end of ear emergence. The last eggs were found in the ears on 20 July (Table 2). The development of these ears was delayed compared with the average for the stand.

The first larvae of $S$. mosellana were also found on $3 \mathrm{July}$, and some were still present in the ears at the end of the sampling period, on 31 Aug. (Table 2). In 921 ears the mean size of a larvae group was 1.58 larvae (per grain):

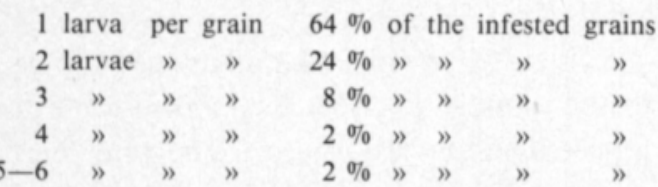

On an average, $21 \%$ of the ears were infested, the mean being 0.9 larvae per ear. The mean ear size was 33 grains, so the proportion of infested grains was ca. $1.7 \%$. There were no clear differences in the level of infestation between different parts of the field.

Table 2. Distribution of finds of $S$. mosellana eggs and larvae on wheat ears during the sampling period.

\begin{tabular}{|c|c|c|c|}
\hline \multicolumn{2}{|c|}{ Sampling date } & \multirow{2}{*}{$\begin{array}{c}\begin{array}{c}\text { Eggs } \% \\
\text { (total 151) }\end{array} \\
-\end{array}$} & \multirow{2}{*}{$\begin{array}{c}\text { Larvae \% } \\
\text { (total 620) } \\
-\end{array}$} \\
\hline June & 29. & & \\
\hline \multirow[t]{9}{*}{ July } & 3. & 5.3 & 0.3 \\
\hline & 6. & - & - \\
\hline & 10. & 1.3 & - \\
\hline & 13. & 4.6 & 9.4 \\
\hline & 17. & 33.8 & 7.4 \\
\hline & 20. & 55.0 & 4.7 \\
\hline & 24. & - & 0.3 \\
\hline & 27. & - & 7.1 \\
\hline & 31. & - & 3.7 \\
\hline \multirow[t]{10}{*}{ August } & 3. & - & 9.2 \\
\hline & 7. & - & 6.8 \\
\hline & 10. & - & 12.6 \\
\hline & 14. & - & 1.8 \\
\hline & 17. & - & 5.8 \\
\hline & 21. & - & 5.8 \\
\hline & 24. & - & 9.8 \\
\hline & 28. & - & 14.0 \\
\hline & 31. & - & 1.3 \\
\hline & & $100 \%$ & $100 \%$ \\
\hline
\end{tabular}

From 10 Aug. onwards, the larvae tended to crawl out of the sampled heads on to the insides of the plastic sample bags during the $2-3$ days' delay before inspection. The ears monitored with the falling traps yielded altogether 54 larvae from 7 Aug. to 21 Aug., at about the yellow ripening stage of the stand. A nine-ear sample of late, still green tillers was taken on 24 Aug., when the rest of the stand was already at the yellow ripening stage. All these late tillers were infested, the mean being 10 larvae per ear.

The crop was harvested on 7 September. The yield was normal, $3770 \mathrm{~kg}$ per ha, and the quality was good. The grain weight was $80.2 \mathrm{~kg}$ per hectolitre.

At Kymenlaakso Research Station, some differences in infestation levels were found between the varieties and lines $(\mathrm{F}(24.24)=$ $\left.4.93^{* * *}\right)$. The highest level of infestation, in Jo 8187 , was 4.1 larvae per ear, which was 20

Number of larvae per ear

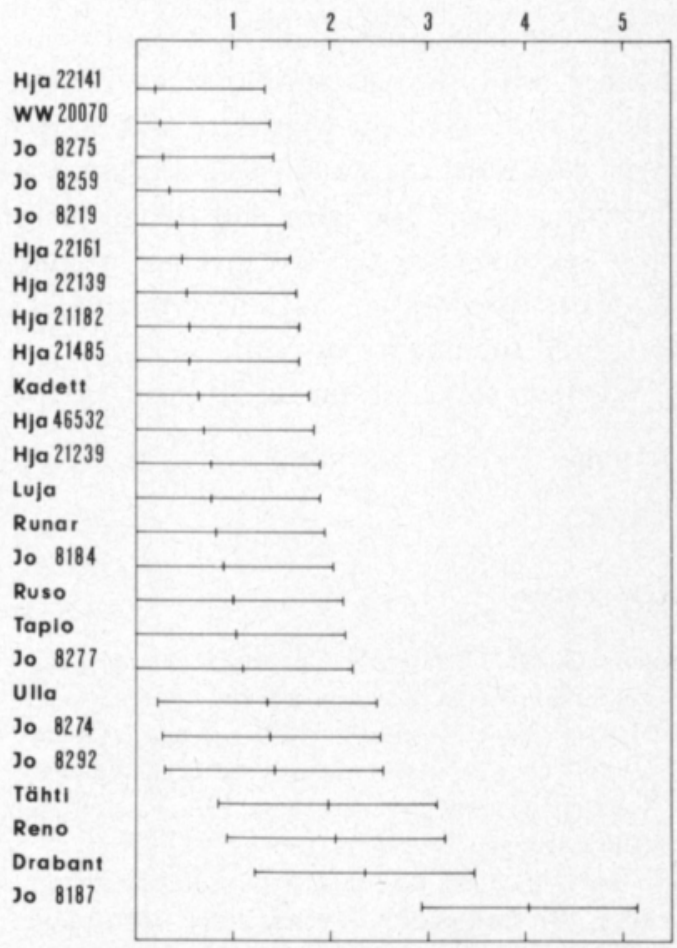

Fig. 1. $95 \%$ comparison intervals obtained by the T-method for the means of infestation by $S$. mosellana larvae of ears of 25 spring wheat varieties. 
times as high as the lowest level, 0.2 larvae per ear in $\mathrm{Hja} 22141$ (Fig. 1). There was no difference in the timing or length of the heading process between Jo 8187 and the less heavily infested varieties.

Six midge specimens from Hankkija Plant Breeding Station and seven from Helsinki University Experiment Farm were determined. They were all found to be Sitodiplosis mosellana (९ ९).

\section{Discussion}

For the first time in Finland, Sitodiplosis mosellana has been reported infesting wheat. The midge wàs abundant not only in the study field, but also in the other locations inspected by chance. As $S$. mosellana was easily found in large numbers, it is likely that it occurs in other wheat-growing areas in Finland as well. It is interesting that the first damage by $S$. mosellana in decades was recently reported from the neighbouring wheatgrowing area in Sweden.

The egg-laying period showed poor coincidence with the susceptible stage of the wheat, as most of the eggs were laid on delayed ears when the stand was already at the flowering stage. The latest individuals were most seriously infested. An average of one larva per ear does not have any notable effect upon the quality of crop.

Whether some of the differences in in-

\section{References}

Ahrén, G. 1982. Erfarenheter av egna försök med Ripcord 1981. Växtskyddsrapp. 20: 82-85.

Andersson, K. \& Nilsson, I. 1980. Vad har vi lärt oss av 1979 års försök med intensifierad bekämpning av svampar och insekter i vete? - Erfarenheter från Södra Sverige. Vaaxtskyddsrapp. 12: 48-53.

Barnes, H. F. 1956. Gall midges of economic importance. VII. Gall midges of cereal crops. 261 p. London.

Basedow. T. \& Gillich, H. 1982. Untersuchungen zur Prognose des Auftretens der Weizengallmücken Con- festation between the varieties could be explained by genetic properties remains to be found out.

Most of the larvae occurred singly. The larvae leave the heads gradually during and after the yellow ripening stage. The use of a plastic cover in the falling traps may have raised the relative humidity, which is known to encourage the descent of larvae (BARNES 1956). This may explain the completion of descent from the monitored ears by as early as 21 Aug.

Evidently, the wheat midges contributed to the damage in 1983. The losses were not repeated in the study year. The poor coincidence of egg laying with the susceptible stage may partly explain the low infestation. There was some evidence on high parasite activity, especially that of Platygasteridae, which are important egg and larval parasites of wheat midges (e.g. BASEDOw \& GiLlich 1982). These preliminary results motivate further studies.

In future work priority should be given to studying the distribution and abundance of $S$. mosellana in Finland, in order to assess the need for control.

Acknowledgements: We are grateful to Mr. W. Nijveldt, Wageningen, the Netherlands, for determining the midges. We should like to thank Ass. Prof., Dr. Anna-Liisa Varis for valuable advice, and Kalevi Virri, the Head of Kymenlaakso Research Station, for help in organizing the work. The English text was revised by Mrs. Anna Damström. tarinia tritici (Kirby) und Sitodiplosis mosellana (Géhin) (Dipt., Cecidomyidae). II. Faktoren, die ein Schadauftreten der Mücken verhindern können. Anz. Schädlingsk. Pflanzensch. Umweltsch. 55: 84-89.

Gol६BıOWSKA, Z. 1980. Wystẹpowanie pryszczarków kwiatowych (Diptera, Cecidomyidae) na klosach pszenicy w Polsce. Materialy XIX Sesji Naukowej Instytutu Ochrony Ros̀lin. Poznań, Poland. Páustwowe Wydawnictwo Rolnicze i Leśne Oddzial w Poznaniu. p. 299-313.

HuKKINEN, Y. \& VAPPULA, N. A. 1936. Überblick über 
das Auftreten von Pflanzenschädlingen in Finnland i J. 1935. J. Scient. Agric. Soc. Finl. 8: 115-122.

LindBlom, A. \& Mühlow, J. 1932. Två undersökningar rörande vetemyggans skadegörelse och ekonomiska betydelse. Meddel. Centralanst. Försöksväsendet Jordbruksomr. 420. 24 p. (Lantbruksent. avd. Nr. 64.)

Müнow, J. 1935. Studier och försök rörande vetemyggorna Contarinia tritici och Clinodiplosis mosellana Géh. samt deras bekämpande. I. Vetemygglarvernas skadegörelse i Sverige åren 1931-1934 samt studier över olika vetesorters angreppsgrad. Stat. Văxtskyddsanst. Medd. 10. 74 p.

- 1936. III. Fältförsők för bekämpning av larverna med kemiska medel. Stat. Växtskyddsanst. Medd. 14. $30 \mathrm{p}$.

— \& SJöerg, K. 1937. V. Fältförsök för bekämpning med kemiska medel av de ăggläggande myggorna i vetefälten. Stat. Växtskyddsanst. Medd. 19. 20 p.

Nisveldt, W. \& Bокноrst, H. J. 1973. Over het optreden en de economische betekenis van de gele en de oranje tarwegalmug (Contarinia tritici Kirby en Sitodiplosis mosellana (Géhin)) in Nederland. Inst. Plantenziektenkundig Onderzoek Wageningen, Nederland, Meded. 629: 59-79.

Swärdson, G. 1940. Studier och försök rörande vetemyggorna Contarinia tritici Kirby och Clinodiplosis mosellana Géh. samt deras bekämpande. VII. Vetemyggornas vindspridning. Stat. Växtskyddsanst. Medd. 31. $36 \mathrm{p}$.

VAPPULA, N. A. 1962. Pests of cultivated plants in Finland. Ann. Agric. Fenn. 1, Suppl. 1. 239 p.

Ms received December 12, 1984

\section{SELOSTUS}

\section{Tähkäsääsken Sitodiplosis mosellana (Géhin) (Dipt., Cecidomyidae) esiintyminen vehnässä}

\author{
Juha Helenius ${ }^{1}$, Jyrki Tomminen ${ }^{1}$ ja \\ Reijo Björkbacka² \\ 1 Maatalous- ja metsäeläintieteen laitos, \\ Helsingin yliopisto, $00710 \mathrm{Helsinki}$ \\ ${ }^{2}$ Kymenlaakson tutkimusasema, Maatalouden \\ tutkimuskeskus, 46910 Anjala
}

Tăhkăsaaăsken esiintymistă seurattiin tähkänäyttein ja pyydyksin kevătvehnäviljelmältä (lajike Hankkijan Taava) Anjalankoskella kasvukauden 1984 ajan. Muninta-aika oli heinäkuun puolivälissä. Täysikasvuiset toukat pudottautuivat tăhkiltă elokuun puolivälistă alkaen. Keskimäärin toukkia oli $0,9 \mathrm{kpl}$ tähkäă kohden, mutta vain noin $20 \%$ tảhkistă oli saastuneita. Toukkaryhmän keskikoko oli 1,58 toukkaa. Noin 1,7 \% jyvistă oli saastuneita. Sadon mäărä viljelmältả oli normaali ja laatu hyvă.

Kymenlaakson tutkimusasemalla otettiin 16. ja 17. 8. tăhkänäytteet kevătvehnän lajikekokeesta 25 lajikkeesta tai linjasta. Saastuneisuus vaihteli merkitsevăsti 4,1 toukasta (Jo 8187) 0,2 toukkaan (Hja 22141) tähkää kohden. Tähkimisajankohta ei selittänyt eroja.

Aikuisia tăhkäsääskinaaraita tavattiin lentelemăssă vehnäkasvustoissa paitsi Anjalankoskella, myös Helsingissä (Viikin koetilalla) ja Tuusulassa (Anttilan koetilalla), eli kaikilla satunnaisesti tarkastetuilla paikoilla. Vaikka tähkäsäăski nyt Suomessa raportoidaan ensimmäisen kerran vehnästä, on syytă epäillä, että laji on vehnänviljelyalueella laajalle levinnyt.

Torjunnan tarpeen arvioimiseksi tulisi tähkäsääsken levinneisyys ja runsaus selvittaaă. 